\title{
KEPUTUSAN PEMBELIAN PADA BRAND AWARENESS SEPATU PAKALOLO
}

\author{
Santi Sartika ${ }^{1}$, Mutia Mawardah ${ }^{2}$ \\ Mahasiswa Universitas Bina Darma ${ }^{1}$, Dosen Universitas Bina Darma ${ }^{2}$ \\ Jalan Jenderal Ahmad Yani No.3 Palembang \\ Sur-el : santysartika05@gmail.com ${ }^{1}$, mutia_mawardah@binadarma.ac.id²
}

\begin{abstract}
This study aims to determine the relationship between brand awareness with the purchase decisions consumer of Pakalolo shoes in the JM Group Palembang. The hypothesis proposed in study is there a relationship between brand awareness with the purchase decisions consumer of Pakalolo shoes in the JM Group Palembang. The population in this study were280 subjects, and sampled as many as 155 subjects. This research used nonprobability sampling technique that is incidental sampling. Researched measuring instruments used the brand awareness with purchase decisions. Analysis techniques using simple regression analysis by using SPSS version 20.0 for windows. The results showed a correlation coefficient $(r)$ of 0,303 with a coefficient of determination (R-square) of 0,092 and $p=0,000(p<0,01)$. This suggests that the hypothesis is accepted. The results showed that there is a very significant relationship between brand awareness with the purchase decisions consumer of Pakalolo shoes in the JM Group Palembang. The contribution of the independent variable on the dependent variable it $9,2 \%$.
\end{abstract}

Keywords: Brand Awareness, Purchase Decisions, Pakalolo Shoes.

Abstrak: Penelitian ini bertujuan untuk mengetahui hubungan antara brand awareness dengan keputusan pembelian konsumen sepatu pakalolo di JM Group Palembang. Hipotesis yang diajukan dalam penelitian ini adalah ada hubungan antara brand awareness dengan keputusan pembelian konsumen sepatu pakalolo di JM Group Palembang. Jumlah populasi dalam penelitian ini sebanyak 280 orang dan yang di jadikan sampel sebanyak 155 orang yang di dapat melalui teknik nonprobability sampling yaitu incidental sampling. Alat ukur yang digunakan dalam penelitian ini adalah skala brand awareness dengan keputusan pembelian. Teknik analisis menggunakan teknik analisis regresi sederhana dengan bantuan SPSS versi 20.0. Hasil analisis data penelitian dengan computer menggunakan program SPSS 20.0 for Windows, menunjukkan koefisien korelasi (r) sebesar 0,303, koefisien determinasi (Rsquare) sebesar 0,092, sertanilai $p=0,000(p<0,01)$ pada uji regresise derhana. Hal ini menunjukkan bahwa hipotesis diterima. Hasil analisis tersebut menunjukkan bahwa ada hubungan yang sangat signifikan antara brand awareness dengan keputusan pembelian konsumen sepatu pakalolo di JM Group Palembang. Komunikasi. Sumbangan variable bebas terhadap variable terikat sebesar $9,2 \%$.

Kata Kunci : brand awareness, KeputusanPembelian, Sepatu Pakalolo

\section{PENDAHULUAN}

Perkembangan dunia bisnis yang semakin pesat dewasa ini menyebabkan perusahaan harus menghadapi persaingan yang ketat dalam hal memasarkan produknya. Berkembangnya ilmu pengetahuan dan teknologi membuat produsen terus berusaha mengembangkan kreativitas dan inovasi-inovasi terbaru dari produk yang dihasilkan agar lebih unggul dari produk pesaing. 
Apabila produk mempunyai kualitas yang kurang baik, maka akan membuat konsumen meninggalkan produk tersebut dan mencari produk lain sehingga mempengaruhi nilai pangsa pasar dari produk yang dihasilkan begitu juga sebaliknya. Hal ini diakibatkan karena adanya arus globalisasi yang semakin terbuka lebar bagi setiap pelaku bisnis. Timbulnya persaingan yang sangat ketat tersebut menyebabkan kalangan usaha saling berlomba untuk dapat menghadapi persaingan dan mendapatkan keunggulan kompetitif (Kotler dan Keller, 2012).

Begitupun dengan sektor industri alas kaki di Indonesia. Di Indonesia total pengeluaran masyarakat untuk memenuhi kebutuhan alas kaki dan pakaian sebesar 2,20 persen serta keperluan untuk kebutuhan pesta sebesar 1,64 persen. Produk alas kaki ini merupakan salah satu produk yang dibutuhkan sehari-hari oleh semua kalangan, mulai dari anak-anak, remaja, sampai orang tua. Saat ini sepatu telah menjadi salah satu kebutuhan fashion yang berperan penting seperti halnya dalam hal busana pakaian. Berbagai model

sepatu yang trend unik dan cantik banyak bermunculan seperti gaya formal yang sempat menjadi trend pada tahun 2013 yang biasanya banyak digunakan oleh para pria dan wanita untuk dating keacara formal maupun nonformal. Namun untuk kegiatan sehari-hari sepatu yang biasa digunakan adalah model sepatu casual dan sporty dimana model sepatu tersebut dirancang senyaman mungkin untuk bisadipakai dikondisi apapun (Wulandari \& Oktafani, 2017).
Dibawah ini merupakan hasil survey yang dilakukan penulis mengenai beberapa jenis merek sepatu yang ada dipalembang terutama di JM Group yaitu: Yongki Komaladi, Fladeo, Homyped, Kasogi, Pricise, Pakalolo, Max barens, Gets,Niel, Gradodan masih banyak merek sepatu pria lainnya. Dari hasil surve penulis menyimpulkan dapat dilihat bahwa pakalolo merupakan merek sepatu yang ada di JM Group. Pakalolo merupakan marek asli indonesia, kata pakalolo di ambil dari bahasa bugis yang artinya: (orang muda suka jalan-jalan) pakalolo dibuat oleh PT.Teguh Murni Perdana (TMP). Perusahaan yang sudah lama bergelut dibisnis sepatudi tahun 1960- an.TMP sudah masuk pasar dengan menggunakan merek Enny shoes, Perusahaan ini didirikan oleh husien pangestu. Pakalolo ini difokuskan untuk sepatu berjenis kulit asli yang diposisikan untuk pasar menengah-atas.

Salah satu perusahaan yang menjual produk fasion terutama dalam bidang sepatu dan sandal merek PAKALOLOyaitu perusahaan JM GROUP.PT.Jaya Masawan Putra Sejahtera yang biasa disebut JM GROUP merupakan salah satu perusahaan retail yang berkembang di Palembang. Perusahaan harus menggunakan metode pemasaran yang modern dengan tujuan agar informasi-informasi tentang produk atas jasa yang ditawarkan dapat diakses oleh target konsumen secara cepat Menurut Kotler dan Keller (2012) pengertian keputusan pembelian adalah tindakan dari konsumen untuk mau membeli atau tidak terhadap produk. Basu dan Handoko (202) menyatakan bahwa keputusan pembelian 
sebenarnya merupakan kumpulan dari sejumlah keputusan yaitu; 1) keputusan tentang jenis produk; 2) keputusan tentang bentuk produk; 3) keputusan tentang merek; 4) keputusan tentang penjualnya; 5) keputusan tentang jumlah produk; 6) keputusan tentang waktu pembelian; 7) keputusan tentang cara pembayaran.

Keputusan pembelian oleh konsumen adalah keputusan yang melibatkan persepsi terhadap kualitas, nilai, dan harga. Konsumen tidak hanya menggunakan harga sebagai indikator kualitas, tetapi juga sebagai indikator biaya yang dikeluarkan untuk ditukar dengan model produk atau manfaat produk. Karenanya, melihat sejauh mana merek yang disandangkan dapat memengaruhi penilaian konsumenterhadap produk tersebut (Romadhoni dan Suprihhadi,2015). Kotler dan Amstrong (2008) menyatakan bahwa bagi konsumen sebenarnya pembelian bukan hanya merupakan satu tindakan saja (misalnya karena produk), melainkan terdiri daribeberapa tindakan yang satu sama lainnya yang saling berkaitan. Dimensi keputusan pembelian terdiri dari; 1) pilihan produk; 2) pilihan merek; 3)pilihan saluran pembelian; 4)waktu pembelian; 5) jumlah pembelian.

Fenomena yang terjadi pada konsumen Pakalolo JM Group Palembang konsumen yang membeli sepatu pakalolo mengatakan bahwa sebelumnya pakalolo memang sudah dikenal banyak orang contohnya bukan hanya ia saja yang telah memakai produk pakalolo tetapi teman-teman kantornya pun banyak yang memakai merek pakalolo. Lalu konsumen yang membeli pakalolo mengatakan bahwa ia sudah terbiasa memakai merek sepatu pakalolo. Selanjutnya konsumen mengatakan ia membeli sepatu pakalolo karena uang yang ia keluarkan sesuai dengan kualitas dan kenyaman yang ia dapatkan dari produk tersebut.

Tujuan dari pelaku usaha untuk meningkatkan kualitas produk kepada konsumen adalah untuk mendapatkan sebuah brand dimata konsumen. Menurut Sunyoto (2012) menyatakan sebuah merek adalah suatu nama, istilah, tanda, atau desain atau gabungan semua yang diharapkan mengidentifikasikan barang atau jasa dari seorang atau kelompok penjual. Hal ini dimaksudkan untuk membedakan suatu perusahaan dengan perusahaan yang lainnya. Dari pendapat tersebut dapat kita simpulkan bahwa jika konsumen merasa produk yang dibelinya adalah produk yang mempunyai kualitas yang baik, maka konsumen akan kembali membeli produk yang ditawarkan. Jika hal itu terus-menerus terjadi, kesadaran merek konsumen pun tinggi ( Wibowo,2017).

Berdasarkan penelitian Ridhania (2012) yang berjudul pengaruh citra merek terhadap gaya keputusan konsumen pada produk starbucks, hasil dari penelitian ini bahwa ada korelasi positif antara citra merek starbucks dengan gaya keputusan konsumen. Dengan kata lain, konsumen mempunyai citra merek yang positif terhadap produk starbucks sehingga mempengaruhi gaya keputusan konsumen. Menurut Drezner (Ridhania, 2012) Merek merupakan entitas kuat karena mencampur nilai fungsional atau performansi dengan nilai emosional.salah satu konsumen 
memilih merek tertentu adalah berdasarkan bagaimana nilai-nilai ini sesuai dengan gaya hidup mereka dan memenuhi serta memuaskan kebutuhan dari konsumen.

Ada tujuh model faktor yang dapat digunakan untuk menjelaskan karakteristik gaya pengambilan keputusan konsumen menurut Sprolles dan Kendal (Ridhania, 2012 salah satunya yaitu; Brand awareness atau dengan kata lain (Brand Conscious) dalam hal ini, orientasi konsumen dalam berbelanja adalah membeli produk yang lebih mahal dengan merek terkenal. Dalam hal ini, diyakini bahwa semakin tinggi harga, maka mutu produk akan semakin baik. Menurut Surachman (2008) kesadaran merek (brand awareness) adalah kesanggupan seorang calon pembeli untuk mengenali atau mengingat kembali bahwa suatu merek merupakan bagian dari kategori tertentu. Kesadaran merek juga dapat diartikan sebagai kekuatan sebuah merek untuk dapat diingat kembali oleh konsumen dan dapat dilihat dari kemampuan konsumen itu sendiri untuk mengidentifikasi merek dalam berbagai kondisi (Krisnawati, 2016).

Piramida kesadaran merek dari tingkat terendah sampai tingkat tertinggi adalah sebagai berikut; 1)Unaware of Brand (Tidak menyadari merek) adalah tingkat paling rendah dalam piramida kesadaran merek, dimana konsumen tidak menyadari adanya suatu merek; 2)Brand Recognition (pengenalan merek) adalah tingkat minimal kesadaran merek, dimana pengenalan suatu merek muncul lagi setelah dilakukan pengingatan kembali lewat bantuan (aided recall); 3)Brand Recall (pengingatan kembali terhadap merek) adalah pengingatan kembali terhadap merek tanpa bantuan (unaided recall); 4)Top of Mind (puncak pikiran) adalah merek yang disebutkan pertama kali oleh konsumen atau yang pertama kali muncul dalam benak konsumen. Berdasarkan Fenomena yang tejadi konsumen mengatakan bahwa telah mengetahui merek ini sejak lama dan pernah memakai produk sepatu dan sudah mengetahui bahwa kualitasnya baik dan tahan lama, jadi ketika ia ingin membeli sepatu yang baik kualitasnya ialah merek pakalolo, dengan merek yang sudah terkenal lama ini jadi sudah menempel dibenak konsumen didukung juga nama brandnya yang unik sehingga mudah diingat.

Ketika sebuah merek memiliki citra yang kuat dan positif dibenak konsumen maka merek tersebut akan selalu diingat dan kemungkinan konsumen untuk membeli merek yang bersangkutan sangat besar. Pada umumnya keputusan pembelian konsumen adalah membeli merek yang paling disukair (Kotler \&Amstrong, 2012).

Piramida kesadaran merek dari tingkat terendah sampai tingkat tertinggi adalah sebagai berikut; 1)Unaware of Brand (Tidak menyadari merek) adalah tingkat paling rendah dalam piramida kesadaran merek, dimana konsumen tidak menyadari adanya suatu merek; 2)Brand Recognition (pengenalan merek) adalah tingkat minimal kesadaran merek, dimana pengenalan suatu merek muncul lagi setelah dilakukan pengingatan kembali lewat bantuan (aided 
recall); 3)Brand Recall (pengingatan kembali terhadap merek) adalah pengingatan kembali terhadap merek tanpa bantuan (unaided recall); 4)Top of Mind (puncak pikiran) adalah merek yang disebutkan pertama kali oleh konsumen atau yang pertama kali muncul dalam benak konsumen. Dengan kata lain, merek tersebut merupakan merek utama dari berbagai merek yang ada dalam benak konsumen (Krisnawati,2016).

Ketika sebuah merek memiliki citra yang kuat dan positif dibenak konsumen maka merek tersebut akan selalu diingat dan kemungkinan konsumen untuk membeli merek yang bersangkutan sangat besar. Pada umumnya keputusan pembelian konsumen adalah membeli merek yang paling disukai (Kotler \&Amstrong, 2012). Berdasarkan Fenomena diatas, peneliti merumuskan masalah yang menarik untuk dikaji yaitu mengetahui "hubungan antara brand awareness dengan keputusan pembelian konsumen sepatu pakalolo yang ada di JM Group Palembang".

Berdasarakan uraian di atas, maka dapat di identifikasikan tujuan dari penelitian ini adalah :" Untuk mengetahui apakah ada hubungan antara brand Awareness dengan keputusan pembelian sepatu pakalolo pada konsumen JM Group Palembang.

\section{METODE PENELITIAN}

Identifikasi variabel penelitian terdiri dari variabel terikat adalah keputusan pembelian dan variabel bebas ada brand awareness

Definisi operasional variabel dalam penelitian ini pengambilan keputusan konsumen merupakan proses yang dilakukan konsumen dalam memilih, membeli dan mengkonsumsi suatu produk atau jasa, sesuai dengan kebutuhan dan keinginannya.

Brand awareness merupakan tujuan umum komunikasi pemasaran, adanya brand awareness yang tinggi di harapkan kapanpun kebutuhan kategori muncul, merek tersebut akan muncul kembali dari ingatan yang selanjutnya dijadikan pertimbangan dalam pengambilan keputusan, brand awareness menunjukan pengetahuan konsumen terhadap eksistensi suatu merek.

Berdasarkan penjelasan di atas maka hipotesis penelitian ini adalah ada Hubungan antara Brand Awareness dengan Keputusan Pembelian Konsumen Sepatu Pakalolo di JM Group Palembang.

Populasi adalah wilayah generalisasi yang terdiri atas: obyek/subjek yang mempunyai kualitas dan karakteristik tertentu yang ditetapkan oleh peneliti untuk dipelajari dan kemudian di tarik kesimpulannya. Sedangkan sampel adalah bagian dari jumlah dan karakteristik yang dimiliki oleh populasi tersebut (Sugiyono, 2017). Sampel pada peneilitian ini adalah 280 konsumen pakalolo yang ada di JM Group Palembang. Sebelum melaksanakan penelitian, peneliti terlebih dahulu melakukan uji coba skala atau TO (Try Out) kepada 122 orang sedangkan sisanya 155 orang dijadikan sampel dalam penelitian ini.

Teknik sampling adalah teknik pengambilan yang dipakai pada penelitian ini adalah teknik Nonprobability Sampling yaitu incidental sampling. Menurut Sugiyono (2017) incidental sampling adalah teknik penentuan 
sampel berdasarkan kebetulan, yaitu siapa saja yang secara kebetulan / incidental bertemu dengan peneliti dapat digunakan sebagai sampel, bila dipandang orang yang kebetulan ditemui itu cocok sebagai narasumber.

Metode pengumpulan data merupakan suatu cara yang digunakan oleh penulis untuk memperoleh data. Metode yang akan digunakan untuk mengumpulkan data pada penelitian ini adalah metode kuantitatif dengan skala sebagai alat pengumpulan data. Skala adalah perangkat pertanyaan yang disusun untuk mengungkap atribut tertentu melalui respon terhadap pertanyaan tersebut (Azwar, 2017)

Skala yang digunakan pada penelitian ini adalah skala yang bersifat tertutup, yaitu dimana subjek diminta untuk memilih salah satu dari beberapa pilihan jawaban yang tersedia. Skala dalam penelitian ini menggunakan skala likert yang dibuat dalam bentuk cheklist. Skala ini terdiri dari dua bentuk pernyataan, yaitu berupa pernyataan yang mendukung (favourable) dan pernyataan yang tidak mendukung (unfavourable). Pemberian skor terhadap masing-masing respond jawaban subjek dinyatakan dalam tabel di bawah ini :

Data dalam penelitian ini diperoleh menggunakan 2 skala yaitu: skala keputusan pembelian dan skala brand awareness. Adapun penjelasan lebih jelas mengenai skala-skala tersebut adalah sebagai berikut:

Skala ini bertujuan untuk mengukur tingkat skala keputusan pembelian pada konsumen sepatu pakalolo di JM Group Palembang. aspek-aspek tertentu dan disajikan dalam blue print. Blue print skala keputusan dibuat berdasarkan aspek keputusan pembelian 64 yang dikemukakan oleh acuan aspek-aspek keputusan pembelian yang dikemukakan oleh Swastha (2010) mengatakan bahwa aspek keputusan konsumen adalah 1) Aspek rasional. 2) Aspek emosional. 3) Aspek behavioral.

Skala brand awareness digunakan untuk mengatahui tingkat brand awreness konsumen sepatu pakalolo di JM Group Palembang. Blue print brand awareness diukur menggunakan tingkatan brand awarenessyang dikemukakan oleh Durianto (yanti, 2010), yaitu; (1) Puncak pikiran (Top of mind); (2) Pengingatan kembali merek (barnd recall); (3)pengenalan merek (brand recognition); (4) tidak menyadari merek (unware of brand).

Validitas adalah untuk mengetahui apakah skala mampu menghasilkan data yang akurat sesuai dengan tujuan ukuran, maka diperlukan suatu proses pengujian validitas atau validasi. Aitem - aitem yang telah diseleksi berdasarkan koefisien aitem total akan mendukung reliabilitas skala. Namun, hal itu tidak berarti bahwa skalanya dinyatakan valid dengan sendirinya. Substansi yang terpenting dalam validasi skala psikologi adalah membuktikan bahwa struktur seluruh aspek, indikator, dan aitem aitemnya memang membentuk suatu konstrak yang akurat bagi atribut yang diukur (Azwar, 2017).Koefisien validitas mempunyai makna jika bergerak dari 0,00 sampai 1,00 . Koefisien yang berkisar antara 0,30 sampai dengan 0,50 telah dapat memberikan kontribusi yang baik dan sudah dianggap memuaskan. Namun, apabila jumlah aitem 
yang lolos ternyata masih tidak mencukupi jumlah yang diinginkan, maka dapat dipertimbangkan untuk menurunkan sedikit batas kriteria dari 0,30 menjadi 0,25 (Azwar, 2017).

Suatu alat tes dicobakan berulang kali pada subjek yang sama sehingga mendapatkan skor yang sama atau relatif sama. Besar koefisien reliabilitas berkisar antara 0,00 sampai dengan 1,00 dan tidak ada patokan pasti. Jika koefisien reliabilitas semakin mendekati 1,00 berarti terdapat konsistensi hasil ukur yang semakin sempurna (Azwar, 2017). Uji reliabilitas pada skala Keputusan pembelian menunjukkan reliabilitas sebesar 0,806.Sedangkan untuk skala brand awareness menunjukkan nilai reliabilitas alpha sebesar 0,828 . Dengan demikian kedua skala tersebut dapat dikatakan memiliki konsistensi hasil ukur yang baik karena nilai reliabilitasnya mendekati 1,00 .

Metode analisis yang digunakan dalam penelitian ini adalah analisis regresi sederhana (simple regression),karena dalam penelitian ini terdapat satu variabel bebas dan satu variabel tergantung. Analisis regresi sederhana digunakan untuk mengetahui korelasi antara keputusan pembelian dengan brand awareness pada konsumen sepatu pakalolo di JM Group Palembang. Uji reliabilitas yang digunakan dalam penelitian ini menggunakan teknik Alpha Cronbach dengan bantuan program komputer SPSS 20.0 (Statistical Package Sosial Science).

Analisis data yang digunakan dalam penelitian ini adalah analisis statistik. Sebelum dilakukan uji hipotesis terlebih dahulu dilakukan uji prasyarat yaitu uji normalitas dan uji linieritas.

\section{HASIL}

Berdasarkan data yang diperoleh melalui tahap uji coba alat ukur, selanjutnya dilakukan uji validitas dan reliabilitas. Perhitungan untuk menguji validitas dan reliabilitas terhadap kedua skala dilakukan dengan bantuan komputer program statistik SPSS (Statistical Package For Social Science) versi 20.00 for windows.

Skala keputusan pembelian yang berjumlah 60 aitem kemudian dilakukan analisis aitem, peneliti menggunakan batas minimum koefisien korelasi 0,30 sehingga diperoleh 49 aitem yang valid dan 11 aitem yang gugur dimana dilakukan analisis sebanyak tiga kali. Analisis pertama terdapat delapan aitem yang gugur yaitu aitem nomer 2,11,23,26,27,29,59,60. Analisis kedua terdapat dua aitem yang gugur yaitu aitem nomer 3 dan 54. Analisis ketiga terdapat satu aitem yang gugur yaitu aitem nomor 21 . Analisis semua aitem valid dengan jumlah 49 aitem.

Skala Brand Awareness yang berjumlah 60 aitem dan terdiri dari 30 pernyataan favourable dan 30 pernyataan unfavourable telah dilakukan analisis validitas dengan batas minimum koefisien korelasi 0,30. Sehingga diperoleh 46 aitem yang valid dan 14 aitem yang gugur dimana dilakukan analisis sebanyak tiga kali. Analisis pertama terdapat 10 aitem yang gugur yaitu aitem nomer $2,8,10,18,20,23,30,35,42,60$. Analisis kedua terdapat tiga aitem yang gugur yaitu 
aitem nomer 15, 19 dan 53. Analisis ketiga terdapat satu aitem yang gugur yaitu aitem nomor 52. Analisis keempat semua aitem valid dengan jumlah 46 aitem.

Berdasarkan data yang didapatkan bahwa dari 155 subjek penelitian subjek laki- laki yang membeli sepatu Pakalolo di JM Group dengan pembelian satu pasang atau lebih dari satu pasang, rata-rata usia yang membeli sepatu Pakalolo di JM Group mulai dari usia 20-40 tahun. Hasil perhitungan statistik menunjukkan bahwa terdapat hubungan yang sangat signifikan antara brand awareness dengan keputusan pembelian konsumen sepatu Pakalolo di JM Group Palembang. Analisis dilakukan dengan menggunakan uji regresi sederhana yang hasilnya menunjukkan adanya penerimaan terhadap hipotesis yang diajukan. Hasil tersebut dapat dilihat dari nilai koefisien korelasi $\mathrm{r}=$ 0,303 atau 30,3\% dengan nilai signifikansi $(\mathrm{P})=$ $0,000 \leq 0,01$. Besarnya nilai sumbangan brand awareness terhadap keputusan pembelian adalah 0,092 atau $9,2 \%$.

Hal ini menunjukkan bahwa ada hubungan yang sangat signifikan antara brand awareness dengan keputusan pembelian konsumen sepatu pakalolo di JM Group Palembang. Berdasarkan data yang didapat di lapangan bahwa brand awareness Pakalolo termasuk dalam kategori tinggi hal ini menunjukan bawa merek sepatu Pakalolo menjadi merek yang paling diingat dibanding dengan merek lain karena nama merek sepatu yang unik dan mudah diingat selain itu juga merek sepatu pakalolo memiliki kualitas yang sangat baik dan berbahan kulit asli. Kebanyakan konsumen yang membeli sepatu pakalolo 66 karena sebelumnya sudah pernah ada pengalaman memakai sepatu pakalolo, pengalaman ini berasal dari dirinya sendiri dan juga pengalaman dari keluarga atau teman terdekan konsumen tersebut sehingga membuat keputusan pembelian konsumen juga tinggi itu artinya kedua variabel berkorelasi positif dimana kedua hubungan ini didukung oleh teori Durianto dkk (2004) kesadaran merek menggambarkan keberadaan merek didalam pikiran konsumen, yang dapat menjadi penentu dalam beberapa kategori dan biasanya mempunyai peran utama dalam brand equity, kesadaran juga mempengaruhi tingkah laku karena kesadaran merek merupakan kunci pembuka untuk masuk kedalam elemen lainnya. Hal ini senada dengan yang dikemukakan oleh Davis (Simamora, 2003) bahwa merek yang kuat memiliki tempat di benak konsumen. Keunikan dari sebuah produk sangatlah penting dalam rangka menciptakan brand awareness suatu produk. Jika produk dapat ditiru formulasinya, maka merek tidak. Karena pada umumnya konsumen membeli merek, bukan produk.

Dari hasil analisa data tersebut, brand awarenesss hanya menyumbang sebesar 9,2\% terhadap keputusan pembelian dan sisanya 90,8\% ditentukan oleh faktor- faktor yang tidak diteliti dalam penelitian ini, seperti yang disebutkan dalam pengambilanvariabel tersebut sama-sama tinggi.

Keputusan konsumen menurut Sprolles dan Kendal (Yanti, 2012) yaitu HighQuality Conscious, Novelty-Fashion Conscious, Recreational Shopping Conscious, 
Price- Value Conscious, Impulsive, Habitual and Brand-Loyal. Hal ini disebabkan karena nama brand sering dibuat candaan bagi yang belum mengenal merek pakalolo dan dari segi persedian warna sepatu formal pakalolo tidak banyak pilihan hampir rata-rata berwarna hitam.

Sehubungan dengan itu menurut Susanto (2005) persyaratan lain bagi nama merek adalah keunikan, yang dapat mencerminkan deferensiasi dan mudah diingat, terutama ingatan tersebut berkaitan dengan asosiasi konsumen dengan atribut utama yang ingin ditonjolkan. Hal ini mengidentifikasi bahwa keunikan dari sebuah merek akan lebih dikenal oleh konsumen karena konsumen membeli mafaat dari sebuah merek. Hal ini sejalan dengan teori yang dikemukakan menurut Rossiter dan Percy (Husni, 2010) konsep kesadaran merek yaitu kemampuan pembeli untuk mengidentifikasi ( mengenal atau mengingat) suatu merek yang cukup detail untuk melakukan pembelian.

\section{Berdasarkan hasil deskripsi kategorisasi} brand awareness bahwa disimpulkan rata-rata konsumen Pakalolo di JM Group memiliki tingkat kesadaran merek yang tinggi. Hal ini tampak dari bentuk kesadaran merek konsumen pada variabel brand awareness memiliki persentase yang tinggi. Berdasarkan hasil survey awal dimana subjek penelitian yang telah menggunakan sepatu Pakalolo selama lebih dari tiga tahun dimana pada saat menggunakan beberapa tahun itu produk Pakalolo tidak rusak atau lepas lem hanya saja selama itu kondisi sepatunya kurang bagus untuk dilihat karena keseringan dipakai tetapi kualitas kulit dan lemnya masih kuat, itulah yang membuat konsumen tertarik menggunakan sepatu Pakalolo kualitas dan ketahanan produk serta kenyaman saat memakai sangat diprioritaskan oleh perusahaan ini, oleh sebab itu berdasarkan hasil penelitian yang dilakukan peneliti ditahun 2018 serta data yang didapatkan berdasarkan jawaban responden pada kuesioner, secara keseluruhan konsumen memiliki kesadaran merek yang tinggi, tercermin pada besarnya nilai rata-rata total sebesar 52,9\% yang memiliki kategori tinggi.

Setiadi (2003) menjelaskan bahwa jika kepercayaan positif terhadap merek, konsumen akan lebih memungkinkan untuk mempunyai sikap positif dan membeli produk itu. Penelitian berikut membahas mengenai brand awareness yang dilakukan oleh Arian (2013) yang berjudul Pengaruh Brand Awareness dan kepercayaan konsumen atas merek terhadap keputusan pembelian minuman Aqua di kota padang pada mahasiswa fakultas ekonomi, Universitas Negeri Padang. Penelitian ini merupakan penelitian kausatif dengan subjek penelitian 150 responden dan tehnik yang digunakan yaitu tehnik sample area . hasil penelitian ini didapatkan bahwa brand awareness berpengaruh signifikan terhadap keputusan pembelian ulang minuman Aqua dikota padang.

Gustafson\&Chabot (Malik dkk, 2013) Kesadaran merek adalah probabilitas bahwa, konsumen sudah familiar tentang ketersediaan dan aksesibilitas a produk dan layanan perusahaan. Jika suatu organisasi memiliki kesadaran merek yang sukses, itu berarti 
bahwa produk dan layanan organisasi memiliki reputasi yang baik di pasar dan dapat diterima. Kesadaran akan merek memainkan peran penting saat membeli produk atau layanan dan mungkin memiliki kontrol pada evaluasi risiko yang dirasakan konsumen dan tingkat kepastian mereka tentang keputusan pembelian karena kesadaran dengan merek dan itu keunikan. Harus ada pertimbangan merek saat mengambil keputusan untuk membeli produk atau layanan, jika ada tidak ada yang perlu dipertimbangkan kemungkinannya adalah tidak ada yang bisa dipilih. Kesadaran merek menciptakan hubungan yang hebat dalam ingatan tentang merek tertentu. Kesadaran merek sangat penting karena jika tidak akan ada kesadaran merek tidak ada komunikasi dan tidak ada transaksi yang akan terjadi (Percy, 1987). Ada dua factor yang mempengaruhi pengambilan keputusan pembelian yang selanjutnya akan menentukan respons konsumen. Pertama, konsumen itu sendiri. Ada dua unsur dari konsumen yang berpengaruh terhadap pengambilan keputusan yaitu pikiran konsumen yang meliputi kebutuhan atau motivasi, persepsi, perilaku konsumen atau karakteristik konsumen yang meliputi demografi, gaya hidup dan kepribadian konsumen. Faktor kedua adalah pengaruh lingkungan yang terdiri atas nilai budaya, pengaruh sub dan lintas budaya, kelas social, face to face group, dan situasi lain yang menentukan.

\section{Menurut}

Machfoeds

mengemukakan bahwa pengambilan keputusan adalah suatu proses penilaian dari berbagai alternatif sesuai dengan kepentingankepentingan tertentu dengan menetapkan suatu pilihan yang dianggap paling menguntungkan. Proses penilaian itu biasanya diawali dengan mengidentifikasi maslah utama yang mempengaruhi tujuan, menyusun, menganalisa, dan memilih berbagai alternatif tersebut dan mengambil keputusan yang dianggap paling baik. Proses pengambilan keputusan pembelian terdiri dari empat tahap. Pada tahap pertama merupakan pemahaman akan adanya masalah. Tahap berikutnya terjadi evaluasi terhadap alternatif yang ada dan tindakan yang paling sesuai dipilih setelah itu pembeli diwujudkan dalam bentuk tindakan, dan akhirnya barang yang dibeli akan digunakan (Engel, dkk. 1995). Tahaptahap keputusan pembelian yang dikemukan Engel (1995) juga didapati pada konsumen dewasa awal di JM Group Palembang, dimana dalam memutuskan membeli suatu produk sepatu Pakalolo, sebagian besar konsumen mamahami akan kebutuhan sepatu yang diperlukan kemudian mengevalusi modelmodel sepatu yang sudah dibeli sebelumnya sehingga akhirnya menjatuhkan pilihan pada sepatu yang sesuai dengan kebutuhan dan akhirnya menggunakan sepatu tersebut dalam beraktifitas.

Penelitian yang dilakukan oleh Krisnawati (2016) yang berjudul pengaruh brand awareness terhadap keputusan pembelian ADMK merek Aqua Masyarakat di kota Bandung pada mahasiswa program studi manajemen UNKRIS Jakarta Timur. Pada penelitian ini hasil yang diperoleh adalah brand awareness berpengaruh signifikan terhadap keputusan pembelian AMDK merek Aqua pada masyarakat di kota bandung. 
Berdasarkan uraian dan hasil analisis data di atas, peneliti menyimpulkan bahwa hipotesis yang diajukan oleh peneliti yaitu ada hubungan antara brand awareness dengan keputusan pembelian konsumen sepatu Pakalolo di JM Group Palembang. Dalam penelitian ini, hipotesis tersebut dapat diterima. Adapun bunyi dari hipotesis penelitian ini berdasarkan hasil analisis data yang telah dilakukan adalah ada hubungan yang sangat signifikan antara brand awareness dengan keputusan pembelian konsumen sepatu Pakalolo di JM Group Palembang.

\section{SIMPULAN}

Berdasarkan hasil yang diperoleh dari analisis data dan pembahasan, maka peneliti menarik kesimpulan bahwa ada hubungan yang sangat signifikan antara brand Awareness dengan keputusan pembelian konsumen sepatu pakalolo di JM Group Palembang.

\section{DAFTAR RUJUKAN}

Azwar, S. (2017). Metode Penelitian Psikologi Edisi II. Yogyakarta: Pustaka Pelajar.

Arian, H. (2013). Pengaruh Brand awareness dan kepercayaan konsumen atas merek terhadap keputusan pembelian ulang minuman Aqua di kota Padang. Fakultas ekonomi, Universitas Negeri Padang.

Durianto. (2004). Brand Equity Ten. Strategi memimpin Pasar. Jakarta: Gramedia pusat Utama.

Engel. J. F., Blackwell. R. D., Miniard. P. W. (1995). Prilaku konsumen.Jilid 2. Jakarta Barat: Binarupa Aksara.

Husni, Achmad Rifqi. (2010). Analisis Pengaruh Brand awareness terhadap Brand Attitude Handphone Merek Nokia. Skripsi Fakultas Ekonomi Universitas Diponegoro

Basu Swastha, Hani Handoko. 2012. Manajemen Pemasaran-Analisis PerilakuKonsumen. Yogyakarta: BPFE

Khisnawati. D. (2016). Pengaruh brand awareness terhadap keputusan pembelian AMDK merek Aqua Bandung: Program Studi Managemen UNKRIS Jatiwaragirin Jakarta Timur.

Kotler dan Keller. 2012. Manajemen Pemasaran. Jilid I. Edisi ke 13 Jakarta: Erlangga.

Kotler, Philip; Armstrong, Garry, 2008. Prinsip-prinsip Pemasaran,Jilid 1, Erlangga, Jakarta.

Malik. E. M.,Dkk (2013). Importance of Brand Awareness and Brand Loyalty in assessing Purchase Intentions of Consumer. USA.International Journal of Business and Social Science.

Machfoedz Mahmud, 2005, Pengantar Pemasaran Modern, edisi pertama, cetakan pertama, Penerbit : UPP AMP YKPN, Yogyakarta 
Romadhoni,Aditya dan Suprihhadi, Heru .,2014.Pengaruh Kesadaran Merek, Asoisasi Merek Terhadap Keputusan Pembelian Shampo Pantene Di Surabaya. Skripsi : Tidak diterbitkan. Sekolah Tinggi Ilmu Ekonomi Indonesia (STIESIA) Surabaya

Ridhania.F.(2012).Pengaruh citra merek terhadap gaya keputusan konsumen pada produck starbuck.Jakarta: Program Studi Psikologi, Fakultas Ilmu Pendidikan, Universitas Negeri Rawamangun Jakarta.

Simamora,Bilson. 2003,Memenangkan Pasar dengan Pemasaran Efektif \&Profitabel,Gramedia Pustaka

Utama,Jakarta.

Setiadi, Nugroho. 2003. "Perilaku Konsumen Konsep dan Implikasi untuk Strategi dan Penelitian Pemasaran". Jakarta: Kencana

Sugiyono.(2012). Metode Penelitian Kuantitatif Kualitatif Dan R\&D. Bandung: Alfabeta.

Sunyoto. D (2012). Konsep Dasar Pemasaran Perilaku Konsumen. Yogyakarta. Caps.

Surachman.2008. Dasar-dasar Manajemen Merek. Banyu Media Publishing.Malang

Susanto. 2004. Power Branding: Membangun Merek Unggul dan Organisasi Pendukungnya, jakarta, penerbit: Mizan Publika Jakarta

Swastha, Basha, Ibnu Sukatjo. 2010. Pengantar Bisnis Liberti, Yogyakarta.

Wibowo. N. E. (2017). Pengaruh brand awareness terhadap keputusan pembelianyellow truck cabang sunda. Bandung; Prodi D3 Manjemen Pemasaran, fakultas ilmu terapan, universitas Telkom.

Wulandari, D. A., Oktafani, F. (2017). Pengaruh brand image terhadap proses keputusan sepatu NIKE. Bandung; Fakultas komunikasi dan bisnis Telkom university bandung.

Yanti, Budiasih. 2012. Statistika Deskriptif Untuk Ekonomi dan Bisnis. Tangerang, Jelajah Nusa. 
